TEME, г. XLII, бр. 3, јул - септембар 2018, стр. 999-1016

Оригинални научни рад

DOI: 10.22190/TEME1803999P

Примљено: 21. 8. 2017.

UDK 338.482(497.11)

Ревидирана верзија: 9. 5. 2018

Одобрено за штампу: 12. 6. 2018.

\title{
PRIORITIZATION OF STRATEGIES FOR TOURISM DEVELOPMENT BY APPLYING A SWOT-SWARA ANALYSIS: THE CASE OF SOKOBANJA SPA
}

\author{
Gabrijela Popović ${ }^{1}$, Goran Milovanović 2 $^{*}$, Dragiša Stanujkić ${ }^{3}$ \\ ${ }^{1}$ Megatrend University, Belgrade, Faculty of Management in Zaječar, Serbia \\ ${ }^{2}$ University of Niš, Faculty of Economics, Niš, Serbia \\ ${ }^{3}$ University of Belgrade, Technical Faculty in Bor, Serbia \\ goran.milovanovic@eknfak.ni.ac.rs
}

\begin{abstract}
This manuscript proposes the utilization of the SWOT-SWARA analysis for the prioritization of tourism development strategies. The applicability and simplicity of the proposed analysis is demonstrated by the example of the tourism destination of Sokobanja Spa in the Republic of Serbia. By using the SWOT analysis, three decision-makers defined the key sub-factors and development strategies, after which they performed the prioritization of the SWOT factors, sub-factors and strategies by applying the SWARA method. The final results are indicative of the following order of the proposed development strategies: $S T_{1} \rightarrow W T_{2} \rightarrow S O_{1} \rightarrow S T_{2} \rightarrow S O_{2} \rightarrow W O_{1}$ $\rightarrow W_{2} \rightarrow W T_{2}$. Applying the proposed strategies by following the given order will contribute to the improvement and further development of the tourism destination of Sokobanja Spa, which is the main goal of the performed analysis.
\end{abstract}

Key words: $\quad$ SWOT analysis, SWARA method, strategy prioritization, Sokobanja Spa.

\section{ПРИОРИТИЗАЦИЈА СТРАТЕГИЈА УСМЕРЕНИХ HА РАЗВОЈ ТУРИЗМА ПРИМЕНОМ SWOT-SWARA АНАЛИЗЕ: ПРИМЕР СОКОБАЊЕ}

\section{Апстракт}

У овом раду је предложена примена SWOT-SWARA анализе за приоритизацију стратегија усмерених на развој туризма. Применљивост и једноставност предложене анализе приказана је на примеру Сокобање, туристичке дестинације која се налази у Републици Србији. Три доносиоца одлуке су уз помоћ SWOT анализе дефинисала кључне потфакторе и развојне стратегије, а затим су извршила приоритизацију SWOT фактора, потфактора и предложених стратегија применом SWARA методе. На основу добијених резултата, утврђен је следећи 
редослед предложених развојних стратегија: $S T_{1} \rightarrow W T_{2} \rightarrow S_{1} \rightarrow S T_{2} \rightarrow S_{2}$ $\rightarrow W O_{1} \rightarrow W O_{2} \rightarrow W T_{2}$. Примена наведених стратегија, према дефинисаном редоследу, допринеће побољшању и даљем развоју туристичке дестинације Сoкобања, што је и основни циљ спроведене анализе.

Кључне речи: SWOT анализа, SWARA метода, приоритизација стратегија, Сокобања.

\section{INTRODUCTION}

Tourism is an economic sector that has dynamically changed over the last decade, primarily because of the diversification of the offered tourism services and products. Nowadays, tourism has become a crucial driver of the socio-economic progress, especially in developing countries. According to the World Tourism Organization - WTO (2017a) - the number of tourist arrivals has continually been increasing and in 2016, it reached a 1.2 billion, while in the Europe the same grew by $2 \%$ relative to 2015, having reached the total of 620 million in 2016 (World Tourism Organization, 2017b).

The situation in the tourism sector of Serbia is similar to that accounted for by the previous data. Namely, the total number of tourist arrivals in 2016 was $2,753,591$, which is $11.5 \%$ more than that generated in previous year (Statistical Office of the Republic of Serbia, 2017). Beside that, a slight increase in the number of foreign tourists during the period from 2011 to 2016 was recorded. Spas are particularly interesting tourism destinations and in 2016 they had a share of $17.3 \%$ in the total tourist arrivals and $27.7 \%$ in the total overnight stays in the Republic of Serbia, resulting in an increased overall tourism operation by $11.6 \%$ relative to that in 2015. According to the tourism operation, Vrnjačka banja Spa ranks the first, with a share of $42.5 \%$ in tourist arrivals and $32.5 \%$ in overnight stays, whereas Sokobanja Spa ranks the second, with a share of $9.6 \%$ in tourist arrivals and $10.5 \%$ in overnight stays.

Sokobanja Spa has quite good preconditions for tourism development and for making an improvement in its current share in the tourism market of the Republic of Serbia and the region. Traditional health and thermal tourism is now accompanied by wellness and fitness tourism, which is predicted to generate a more dynamic development in a future period, because of the modern lifestyle (Csirmaz \& Petö, 2015), which represents a development chance for Sokobanja Spa. There are a lot of issues that have to be resolved, such as: the tourism and the communal infrastructures, the quality and the number of accommodation facilities, the better utilization of the available natural resources and better-designed tourism content. By applying an appropriate strategy, however, it would be possible to overcome the mentioned issues and increase Sokobanja Spa's tourism operation volume as well. 
In order to foster the development of Sokobanja Spa, it is necessary to detect what the main benefits and the key deficiencies of this tourism destination are, formulate strategies for enhancing tourism development and, then, conduct its prioritization for the purpose of determining which strategy has a priority when the application of the same is concerned in the present conditions. This manuscript proposes the application of the SWOTSWARA analysis for the prioritization of the strategies intended for the development of Sokobanja Spa. The main goal is to define the order of the strategies that should be used for improving the present state of Sokobanja Spa, as well as to show the applicability and simplicity of the SWARA method, which contributes to the decision-making process by facilitating the prioritization of the strategies formulated by applying the SWOT analysis. The manuscript consists of four parts, beside the introduction and conclusion. The first part provides the literature review that is relevant to the research area. The explanation of the SWARA method is given in the second part. The application of the SWOT-SWARA analysis is shown in the third part. The last part contains a discussion of the obtained results.

\section{LITERATURE REVIEW}

Making an optimal decision is a very hard and complex task for decision-makers $(D M)$ because an appropriate solution depends on both internal (strengths, weaknesses) and external (opportunities, threats) factors. A combination of these factors with the main goal of defining a strategic action that will bring desired benefits in a future period is reflected through the ideas of Selznick, Drucker and Chandler, and finally generalized by Andrews (1965) as the SWOT analysis. The SWOT analysis is used for the identification of the internal strengths and weaknesses, as well as for the external opportunities and threats, that could either enhance or hinder the achievement of the full business potential (Coman \& Ronen, 2009; Houben et al., 1999). The identification and grouping of the SWOT factors represent the first phase in strategic decision-making (Helms \& Nixon, 2010).

Beside the fact that the SWOT analysis is still a very popular and powerful tool for making a diagnosis of the present state and the defining of the key factors influencing strategic decisions and, indirectly, the business position, it has some flaws. The main flaw of the SWOT analysis is that it is very difficult to define which factors have the greatest impact on the final decision (Kurttila et al., 2000), as well as its inability to generate the quantitative expression of the significance of the mentioned factors (Esmaeili et al., 2014). However, these flaws could be overcome by combining the Multiple-Criteria Decision-Making methods (MCDM) with the SWOT analysis (Kajanus et al., 2012). 
MCDM is a fastest-growing part of the management science that has gained a significant popularity in scientific communities. Many different methods have been developed for the purpose of resolving various types of real-world decision-making problems connected with: the supplier selection (Chai et al., 2013), the technology selection (Oztaysi, 2014), the personnel selection (Karabasevic et al., 2016), the tourism and hotel industry (Mardani et al., 2016), etc. In this manuscript, the new Step-wise Weight Assessment Ratio Analysis (SWARA) is proposed for the purpose of prioritizing development strategies for Sokobanja Spa.

The SWARA method introduced by Keršuliene et al. (2010) is very useful and facilitates the decision-making process in many different fields (Hashemkhani Zolfani \& Bahrami, 2014; Karabašević et al., 2016; Zolfani et al., 2013). Very often, this method is used to determine the weights of criteria. In the field of tourism, the SWARA method is used to find a solution to the problem of the hotel selection, in combination with the Operational Competitiveness Rating Analysis (OCRA) (Iş1k \& Adalı, 2016), and to solve the personnel selection problem, too (Urošević et al., 2017). Despite that, there is enough room for a further observation of the possibilities for the application of the SWARA method in the decisionmaking process in the field of tourism.

A combination of the SWOT analysis and MCDM methods has been proposed for an application in strategic decision-making in various business fields, and the most used hybrid model is that based on the combination of the SWOT analysis and the Analytic Hierarchy Process (AHP) (Eslamipoor \& Sepehriar, 2014; Shahba et al., 2017; Şeker \& Özgürler, 2012). Also, the mentioned combination of the SWOT analysis and AHP method is used in tourism for defining the key influential factors as well as prioritizing the strategies. The examples for that are the manuscripts by: Lee and Liu (2011), Mimović et al. (2012), Akbulak and Cengiz (2014), and Nikolić et al. (2015).

Beside the fact that the most often used hybrid model for the prioritization of development strategies in the field of tourism relies on the SWOT analysis and the AHP method, there are examples where the SWOT analysis is used together with other MCDM methods for the same purpose. For example, Singh et al. (2015) applied the quantitative multicriteria futuristic fuzzy decision hierarchy (MFFDH) together with the SWOT analysis in order to determine the importance of the factors significant for the development of the tourism industry in Agra, India, and perform their ranking. The prioritization of strategies, determined with the help of the SWOT analysis and the TOWS matrix which enhance the development of ecotourism in the National Park of Djerdap is achieved by using the ordinary and fuzzy Analytical Network Process (ANP) (Arsić et al., 2017). Asadi (2011) defined the strategies for cultural tourism development in Iran by applying the SWOT analysis and ranked them by using the Technique for 
Order of Preference by Similarity to Ideal Solution (TOPSIS), while Ajmera (2017) applied the same combination of the methods for classifying the strategies aimed at developing the Indian medical tourism sector. For the same purpose for which the defining and prioritizing of the crucial factors and strategies for the development of the tourism Sokobanja Spa are implicated, the adoption of the SWOT-SWARA combination used by Jamali et al. (2017) for the ranking and selection of the supply chain management concurrent strategies in Iranian cement industries is proposed, though there have been no examples of putting this kind of model into practice in the field of tourism development yet.

Taking into consideration the fact that there are a lot of different MCDM methods, it is desirable to exam the possibilities of their combining with the SWOT analysis with the goal of defining new hybrid models, adequate for an application in business decision-making. Therefore, the authors of the manuscript propose a combined application of the SWOT and the SWARA methods for the prioritizing of both the factors and the defined strategies. The main goal is to facilitate the decision-making process, perform the quantification of the SWOT factors, determine the importance of every one of them and conduct the prioritization of the strategies that should be applied so as to improve the present state of the tourism destination.

\section{SWARA METHOD}

The SWARA method (Keršuliene et al., 2010) is similar to the AHP method (Saaty, 1980), but has certain unique specificities of its own as well. Namely, as stated in the paper by Stanujkić et al. (2015), in both methods there is an evident need for pairwise comparisons, with the aim of determining the importance of the criteria involved in the decisionmaking process. However, while the AHP method entails checking the consistency of the comparisons made, the SWARA method does not involve such a verification of the obtained results. Also, the procedures of both methods require the application of a predetermined scale. The AHP method uses a nine-point scale, whereas in the SWARA method DMs express their attitudes about the significance of the criteria by attributing a value from interval 0 to interval 1 to them.

$D M$ s play a very important role in the SWARA method because their attitudes have a great influence on the process of determining criteria significance, as well as on their final rank. In that process, every $D M$ uses his/her knowledge and experience and the available piece of information (Hashemkhani Zolfani \& Saparauskas, 2013). This method is very useful when group decision-making is being performed because it is simple and easy to use. Besides, when the decision-making process is 
being conducted in the conditions implying the policies having formerly been defined and the priorities being known, there is no need for any previous ranking of the criteria.

Keršuliene et al. (2010) introduced the procedure of criteria weights determination, which was later slightly simplified by Stanujkić et al. (2015). The usefulness of the simplified procedure is confirmed in the papers by Urošević et al. (2017), Karabašević and Stanujkić (2017) and Karabašević et al. (2017), and here it is presented through the following steps.

Step 1. The criteria need to be sorted in descending order, according to the expected significances.

Step 2. The DM should express the relative importance of the criterion $j$ relative to the previous criterion $(j-1)$ for every particular criterion, starting from the second. follows:

Step 3. In the third step, the coefficient $k_{j}$ should be performed, as

$$
k_{j}=\left\{\begin{array}{cc}
1 & j=1 \\
s_{j}+1 & j>1
\end{array}\right\},
$$

where $s_{j}$ represents the ratio of the comparative importance of the average value. follows:

Step 4. The recalculated weight $q_{j}$ should be determined as

$$
q_{j}=\left\{\begin{array}{cc}
1 & j=1 \\
\frac{k_{j}-1}{k_{j}} & j>1
\end{array}\right\} .
$$

Step 5. The relative weights of the criteria should be performed by using Eq. (3):

$$
w_{j}=\frac{q_{j}}{\sum_{k=1}^{n} q_{k}},
$$

where $w_{j}$ denotes the relative weights of the criterion $j$.

Step 6. In the end, the alternatives are ranked in ascending order and the best alternative is the one with the highest $w_{\mathrm{j}}$.

The main advantage of the SWARA method compared to the AHP method is reflected through a much smaller number of pairwise comparisons. Although the AHP method entails checking the consistency of the performed comparisons, a larger number of the criteria involved in the decision-making process significantly complicate the procedure, which could eventually result in the promulgation of an inappropriate decision. Even though the SWARA method does not imply consistency checking, the simplicity of the procedure decreases a chance for an inconsistency to occur. Another advantage of the SWARA method is that it can be used by ordinary respondents having no previous experience in 
using this kind of method and that it does not require intense preceding training. The mentioned advantages of the SWARA method impose it as a suitable technique that could be used together with the SWOT analysis in the prioritizing of factors and strategies in a certain field, which will contribute to overcoming the deficiencies of the AHP method.

The SWOT-SWARA combination is seen as an adequate approach that could also facilitate the decision-making process and strategy prioritization in the field of tourism development. Beside the fact that the authors of this paper have performed the estimation of the given factors and strategies, tourism workers and other experts who have not previously used this method in the decision-making process could also be involved. This is enabled by the fact that the procedure of applying the proposed method could be very easily explained to respondents. Also, in the SWARA method, a complex evaluation procedure is avoided, which facilitates the promulgation of the final decision. Because the priorities for tourism development are generally defined, it is much easier to perform the prioritization of the factors and the given strategies and obtain results from a greater number of different DMs. All of the foregoing favors the application of the proposed combination of the methods not only in the field of tourism and tourism development, but also in other business fields.

\section{APPLICATION OF THE SWOT-SWARA ANALYSIS}

Sokobanja Spa is situated in the central area of Eastern Serbia and has relatively favorable preconditions for tourism development. There are, however, some issues that Sokobanja Spa should overcome in order for it to achieve better business results and a better position on the tourism market. There is a necessity for a systematic approach to finding the optimal solutions expressed through the appropriate strategies that have to be used with the goal of improving the present state and the further development of Sokobanja Spa. Because of that, the application of the proposed hybrid model relying on the SWOT-SWARA analysis is proposed and the same could be presented through the following series of six steps.

Step 1. Based on the SWOT analysis presented in the Master Plan of the Tourism Destination of Sokobanja Spa (Ministry of Trade, Tourism and Telecommunications, 2007), the authors (hereinafter referred to as $D M$ s) made a new one, with a smaller number of sub-factors. After that, they defined the strategies (strengths-opportunities $-\boldsymbol{S O}$, strengths-threats - $\boldsymbol{S T}$, weaknesses-opportunities - WO, weaknesses-threats - WT) that could enhance the development of the mentioned tourism destination. The results of the conducted SWOT analysis and the proposed strategies are presented in Table 1 . 
Table 1. The SWOT matrix for Sokobanja Spa

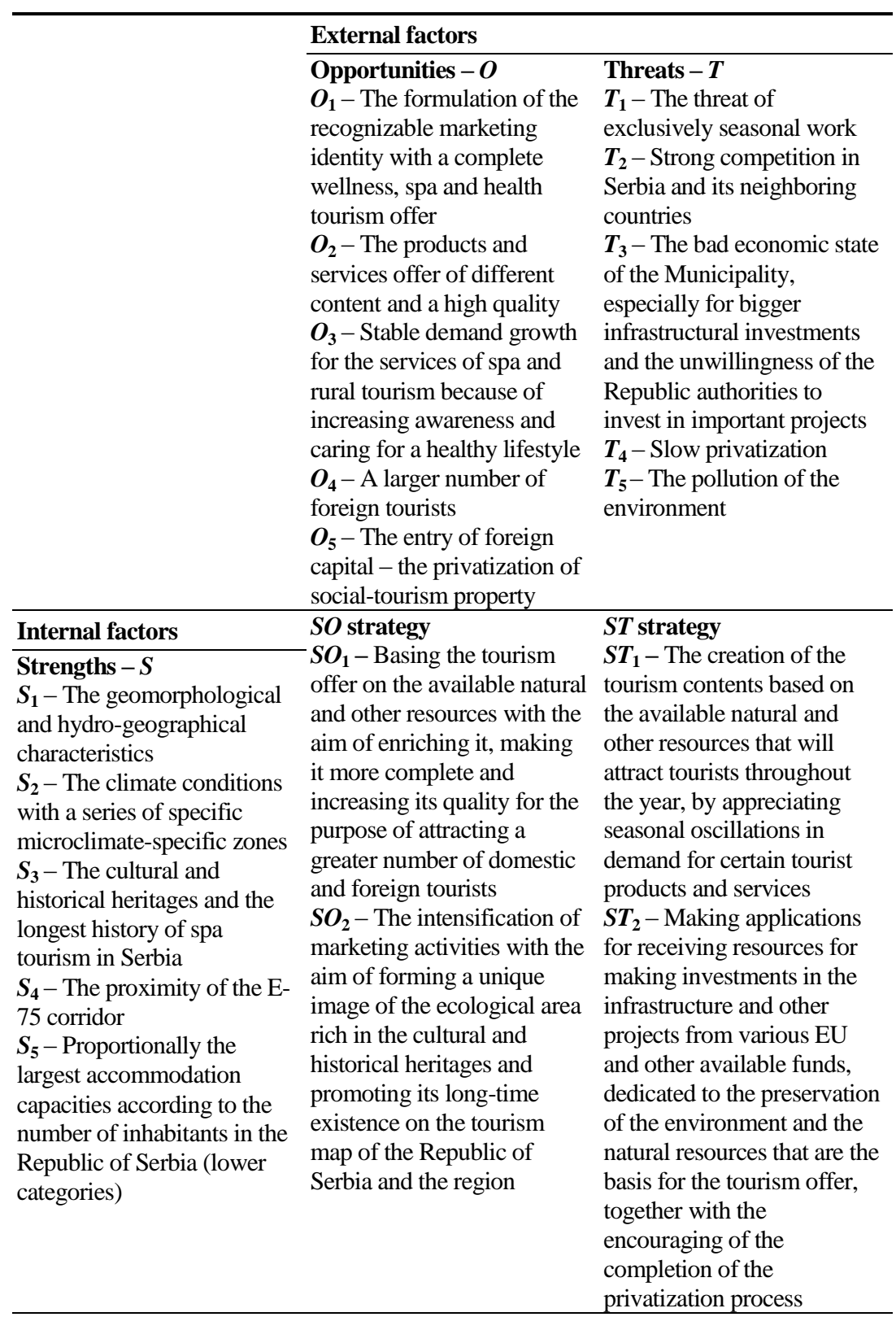




\begin{tabular}{|c|c|c|}
\hline $\begin{array}{l}\text { Weaknesses - } \boldsymbol{W} \\
\boldsymbol{W}_{\mathbf{1}}-\text { The bad traffic } \\
\text { infrastructure (especially at } \\
\text { the access to the } \\
\text { municipality of Sokobanja } \\
\text { Spa) } \\
\boldsymbol{W}_{\mathbf{2}}-\text { Poor investments in all } \\
\text { of the segments of the } \\
\text { tourism infrastructure and } \\
\text { the bad communal } \\
\text { infrastructure of the } \\
\text { hospitality capacities } \\
\boldsymbol{W}_{\mathbf{3}}-\text { A big number of } \\
\text { unreported guests in private } \\
\text { accommodations } \\
\boldsymbol{W}_{\mathbf{4}}-\text { Prices do not follow } \\
\text { the quality of the offer, nor } \\
\text { that of demand (especially } \\
\text { that regarding seasonality) } \\
\boldsymbol{W}_{\mathbf{5}}-\text { High investments in } \\
\text { the construction of the } \\
\text { necessary communal } \\
\text { infrastructure }\end{array}$ & $\begin{array}{l}\text { WO strategy } \\
\boldsymbol{W O}_{\mathbf{1}} \text { - The regulation of } \\
\text { property-legal relations, the } \\
\text { completion of the } \\
\text { privatization of the social- } \\
\text { tourism property, as well as } \\
\text { the resourcing of } \\
\text { investments in the tourism } \\
\text { infrastructure that will } \\
\text { contribute to overcoming } \\
\text { the existing problems and to } \\
\text { making an increase in the } \\
\text { quality of the } \\
\text { accommodation and other } \\
\text { tourism capacities, as well } \\
\text { as to a further tourism } \\
\text { development of the } \\
\text { destination itself } \\
\text { WO } \boldsymbol{O}_{2}-\text { Creating a } \\
\text { recognizable identity, based } \\
\text { on a diverse tourism offer } \\
\text { that could satisfy the tastes } \\
\text { and the possibilities of the } \\
\text { different types of tourists, } \\
\text { accompanied by the } \\
\text { convergence of the price } \\
\text { and the quality of the } \\
\text { services provided }\end{array}$ & $\begin{array}{l}W T \text { strategy } \\
W T_{1}-\text { Defining the } \\
\text { standards for increasing and } \\
\text { the preservation of the } \\
\text { quality of the environment, } \\
\text { which is the basis for } \\
\text { tourism development, as } \\
\text { well as the regulation of } \\
\text { business and property-legal } \\
\text { relations in order to } \\
\text { increase the competitiveness } \\
\text { of Sokobanja Spa on the } \\
\text { tourism market } \\
\boldsymbol{W} \boldsymbol{T}_{2}-\text { The preparation of } \\
\text { project proposals made to } \\
\text { Republic and other } \\
\text { institutions, intended for } \\
\text { solving the problems of the } \\
\text { bad traffic, communal and } \\
\text { tourism infrastructures }\end{array}$ \\
\hline
\end{tabular}

Source: (Ministry of Trade, Tourism and Telecommunications, 2007)

Step 2. In this step, each $D M$ determines the importance of the SWOT factors by using Eqs (1)-(3). After that, the overall importance of the considered factors is determined by using the following Eqs:

$$
\begin{aligned}
& G M_{j}=\left(\prod_{k=1}^{K} w_{j}^{k}\right)^{1 / K}, \\
& w_{j}=G M_{j} / \sum_{l=1}^{n} G M_{l},
\end{aligned}
$$

where $G M_{j}$ represents the geometric mean of the importance obtained from the DMs involved in the evaluation of the factor $j, w_{j}$ denotes the importance of the factor $j$ and $K$ is the number of the DMs.

Table 2. The importance of the SWOT factors according to the DMs

\begin{tabular}{ccccc}
\hline & $D M_{1}$ & $D M_{2}$ & $D M_{3}$ & $\begin{array}{c}\text { Overall } \\
\text { importance }\end{array}$ \\
\hline $\boldsymbol{S}$ & 0.4468 & 0.2097 & 0.2520 & $\mathbf{0 . 3 0 5 1}$ \\
$\boldsymbol{W}$ & 0.1064 & 0.3774 & 0.2291 & $\mathbf{0 . 2 2 2 8}$ \\
$\boldsymbol{O}$ & 0.2979 & 0.1613 & 0.2291 & $\mathbf{0 . 2 3 6 6}$ \\
$\boldsymbol{T}$ & 0.1489 & 0.2516 & 0.2898 & $\mathbf{0 . 2 3 5 5}$ \\
\hline
\end{tabular}


As Table 2 shows, the factor $S$ - strengths (0.3051) has the greatest importance, whereas the factor $\boldsymbol{O}$ - opportunities $(0.2366)$ has a slightly larger importance relative to the $\boldsymbol{T}$ - threats $(0.2355)$ and $\boldsymbol{W}$ - weaknesses (0.2228).

Step 3. The local importance of each SWOT sub-factor is determined by the $D M$ s involved in the procedure by applying the previously mentioned Eqs (1)-(3), which is only followed by the defining of the overall importance of each sub-factor by applying Eqs (4) and (5).

Table 3. The importance of the "strengths" sub-factor according to the DMs

\begin{tabular}{ccccc}
\hline & $D M_{1}$ & $D M_{2}$ & $D M_{3}$ & $\begin{array}{c}\text { Overall } \\
\text { importance }\end{array}$ \\
\hline $\boldsymbol{S}_{\mathbf{1}}$ & 0.3710 & 0.3630 & 0.1916 & $\mathbf{0 . 3 0 7 0}$ \\
$\boldsymbol{S}_{\mathbf{2}}$ & 0.1767 & 0.2420 & 0.2414 & $\mathbf{0 . 2 2 6 2}$ \\
$\boldsymbol{S}_{\mathbf{3}}$ & 0.2650 & 0.1235 & 0.1916 & $\mathbf{0 . 1 9 1 6}$ \\
$\boldsymbol{S}_{\mathbf{4}}$ & 0.0892 & 0.1728 & 0.2012 & $\mathbf{0 . 1 5 1 5}$ \\
$\boldsymbol{S}_{\mathbf{5}}$ & 0.0981 & 0.0988 & 0.1742 & $\mathbf{0 . 1 2 3 7}$ \\
\hline
\end{tabular}

According to the results accounted for in Table 3, the greatest overall importance is that of the sub-factor $S_{1}(0.3070)$, whereas the smallest importance is that of the sub-factor $\boldsymbol{S}_{\mathbf{5}}(0.1237)$.

Table 4. The importance of the "weaknesses" sub-factor according to the DMs

\begin{tabular}{ccccc}
\hline & $D M_{1}$ & $D M_{2}$ & $D M_{3}$ & $\begin{array}{c}\text { Overall } \\
\text { importance }\end{array}$ \\
\hline $\boldsymbol{W}_{\mathbf{1}}$ & 0.4518 & 0.1681 & 0.2634 & $\mathbf{0 . 2 8 9 1}$ \\
$\boldsymbol{W}_{\mathbf{2}}$ & 0.2378 & 0.3765 & 0.1996 & $\mathbf{0 . 2 7 8 4}$ \\
$\boldsymbol{W}_{\mathbf{3}}$ & 0.1640 & 0.1000 & 0.1512 & $\mathbf{0 . 1 4 4 1}$ \\
$\boldsymbol{W}_{\mathbf{4}}$ & 0.0911 & 0.2353 & 0.2195 & $\mathbf{0 . 1 7 8 4}$ \\
$\boldsymbol{W}_{\mathbf{5}}$ & 0.0552 & 0.1201 & 0.1663 & $\mathbf{0 . 1 1 0 0}$ \\
\hline
\end{tabular}

The results from Table 4 show that the sub-factor $\boldsymbol{W}_{\mathbf{1}}(0.2891)$ has the greatest importance relative to the others, whereas the least importance is that of the sub-factor $\boldsymbol{W}_{\mathbf{5}}(0.1100)$.

Table 5. The importance of the "opportunities" sub-factor according to the DMs

\begin{tabular}{ccccc}
\hline & $D M_{1}$ & $D M_{2}$ & $D M_{3}$ & $\begin{array}{c}\text { Overall } \\
\text { importance }\end{array}$ \\
\hline $\boldsymbol{O}_{\mathbf{1}}$ & 0.4629 & 0.1105 & 0.2281 & $\mathbf{0 . 2 5 9 1}$ \\
$\boldsymbol{O}_{\mathbf{2}}$ & 0.0668 & 0.3907 & 0.1975 & $\mathbf{0 . 1 9 7 3}$ \\
$\boldsymbol{O}_{\mathbf{3}}$ & 0.2645 & 0.2299 & 0.1791 & $\mathbf{0 . 2 5 3 2}$ \\
$\boldsymbol{O}_{\mathbf{4}}$ & 0.1323 & 0.0921 & 0.1881 & $\mathbf{0 . 1 5 0 6}$ \\
$\boldsymbol{O}_{\mathbf{5}}$ & 0.0735 & 0.1201 & 0.2073 & $\mathbf{0 . 1 3 9 7}$ \\
\hline
\end{tabular}


When the sub-factors are connected with the opportunities in question, the sub-factor $\boldsymbol{O}_{\mathbf{1}}(0.2591)$ is the best-ranked, whereas the subfactor $\boldsymbol{O}_{\mathbf{5}}(0.1397)$ ranks the last (Table 5).

Table 6. Importance of the "threats" sub-factor according to the DMs

\begin{tabular}{ccccc}
\hline & $D M_{1}$ & $D M_{2}$ & $D M_{3}$ & $\begin{array}{c}\text { Overall } \\
\text { importance }\end{array}$ \\
\hline $\boldsymbol{T}_{\mathbf{1}}$ & 0.2165 & 0.2376 & 0.1920 & $\mathbf{0 . 2 2 3 8}$ \\
$\boldsymbol{T}_{\mathbf{2}}$ & 0.1025 & 0.0870 & 0.2496 & $\mathbf{0 . 1 3 6 2}$ \\
$\boldsymbol{T}_{\mathbf{3}}$ & 0.4330 & 0.4039 & 0.1920 & $\mathbf{0 . 3 3 6 6}$ \\
$\boldsymbol{T}_{\mathbf{4}}$ & 0.1128 & 0.1131 & 0.1745 & $\mathbf{0 . 1 3 6 2}$ \\
$\boldsymbol{T}_{\mathbf{5}}$ & 0.1353 & 0.1584 & 0.1920 & $\mathbf{0 . 1 6 7 2}$ \\
\hline
\end{tabular}

The sub-factor $\boldsymbol{T}_{\mathbf{3}}(0.3366)$ has the greatest overall importance, whereas the sub-factors $\boldsymbol{T}_{\mathbf{2}}(0.1362)$ and $\boldsymbol{T}_{\mathbf{4}}(0.1362)$ share the last place, as is shown in Table 6.

Step 4. In this step, the mutual multiplying of the obtained local importance of the SWOT factors and sub-factors from Steps $\mathbf{2}$ and $\mathbf{3}$ is done, resulting in the global importance of the SWOT sub-factors (Table 7).

Table 7. The global importance of the SWOT sub-factors

\begin{tabular}{|c|c|c|c|c|}
\hline SWOT groups & $\begin{array}{c}\text { Importance } \\
\text { of the SWOT } \\
\text { factor }\end{array}$ & $\begin{array}{c}\text { SWOT } \\
\text { sub-factors }\end{array}$ & $\begin{array}{c}\text { Local } \\
\text { importance of } \\
\text { SWOT } \\
\text { sub-factors }\end{array}$ & $\begin{array}{c}\text { The global } \\
\text { importance of } \\
\text { SWOT } \\
\text { sub-factors }\end{array}$ \\
\hline \multirow{5}{*}{$S$} & \multirow{5}{*}{0.3051} & $S_{1}$ & 0.3070 & $\mathbf{0 . 0 9 3 7}$ \\
\hline & & $S_{2}$ & 0.2262 & 0.0690 \\
\hline & & $S_{3}$ & 0.1916 & 0.0584 \\
\hline & & $S_{4}$ & 0.1515 & 0.0462 \\
\hline & & $S_{5}$ & 0.1237 & 0.0377 \\
\hline \multirow{5}{*}{$\boldsymbol{W}$} & \multirow{5}{*}{0.2228} & $W_{1}$ & 0.2891 & 0.0644 \\
\hline & & $W_{2}$ & 0.2784 & 0.0620 \\
\hline & & $W_{3}$ & 0.1441 & 0.0321 \\
\hline & & $W_{4}$ & 0.1784 & 0.0398 \\
\hline & & $W_{5}$ & 0.1100 & 0.0245 \\
\hline \multirow{5}{*}{$O$} & \multirow{5}{*}{0.2366} & $O_{1}$ & 0.2591 & 0.0613 \\
\hline & & $\mathrm{O}_{2}$ & 0.1973 & 0.0467 \\
\hline & & $\mathrm{O}_{3}$ & 0.2532 & 0.0599 \\
\hline & & $\mathrm{O}_{4}$ & 0.1506 & 0.0356 \\
\hline & & $\mathrm{O}_{5}$ & 0.1397 & 0.0331 \\
\hline \multirow{5}{*}{$T$} & \multirow{5}{*}{0.2355} & $T_{1}$ & 0.2238 & 0.0527 \\
\hline & & $T_{2}$ & 0.1362 & 0.0321 \\
\hline & & $T_{3}$ & 0.3366 & 0.0793 \\
\hline & & $T_{4}$ & 0.1362 & 0.0321 \\
\hline & & $T_{5}$ & 0.1672 & 0.0394 \\
\hline
\end{tabular}


In the $\boldsymbol{S}$-group, the sub-factor $\boldsymbol{S}_{\mathbf{1}}-$ Geomorphological and hydrogeographical characteristics (0.0937) has a dominant influence; in the $\boldsymbol{W}$ group, the domination is attributed to the sub-factor $\boldsymbol{W}_{\mathbf{1}}-$ Bad traffic infrastructure (especially at the access to the Municipality of Sokobanja Spa) (0.0644); $\boldsymbol{O}_{\mathbf{1}}$ - The formulation of the recognizable marketing identity with a complete wellness, spa and health tourism offer (0.0613) has the greatest global importance in the $\boldsymbol{O}$-group; ultimately, $\boldsymbol{T}_{\mathbf{3}}-$ The bad economic state of the Municipality, especially with respect to bigger infrastructural investments and the unwillingness of the Republic authorities to invest in significant projects (0.0793), has the significantly greatest overall global importance in the $\boldsymbol{T}$-group.

Step 5. The DMs determine the importance of the defined strategies relative to the SWOT sub-factors by applying Eqs (1)-(3). Then, by applying Eqs (4) and (5), the overall importance of each alternative strategy is determined and they are shown in Table $8 a$ and Table $8 b$.

Table 8a. The overall importance of each alternative strategy according to the "strengths" and "weaknesses" sub-factors

\begin{tabular}{ccccccccccc}
\hline & $\boldsymbol{S}_{\mathbf{1}}$ & $\boldsymbol{S}_{\mathbf{2}}$ & $\boldsymbol{S}_{\mathbf{3}}$ & $\boldsymbol{S}_{\mathbf{4}}$ & $\boldsymbol{S}_{\mathbf{5}}$ & $\boldsymbol{W}_{\mathbf{1}}$ & $\boldsymbol{W}_{\mathbf{2}}$ & $\boldsymbol{W}_{\mathbf{3}}$ & $\boldsymbol{W}_{\mathbf{4}}$ & $\boldsymbol{W}_{\mathbf{5}}$ \\
\hline $\boldsymbol{S O}_{\mathbf{1}}$ & 0.2402 & 0.3332 & 0.1661 & 0.0191 & 0.4195 & 0.0348 & 0.0278 & 0.0311 & 0.1211 & 0.0263 \\
$\boldsymbol{S O}_{\mathbf{2}}$ & 0.1338 & 0.2104 & 0.3543 & 0.0597 & 0.1658 & 0.0560 & 0.0315 & 0.0370 & 0.0543 & 0.0377 \\
$\boldsymbol{S T}_{\mathbf{1}}$ & 0.2553 & 0.1847 & 0.1906 & 0.0573 & 0.1347 & 0.0466 & 0.0489 & 0.0822 & 0.1993 & 0.0522 \\
$\boldsymbol{S T}_{\mathbf{2}}$ & 0.0566 & 0.0450 & 0.0348 & 0.2271 & 0.0463 & 0.2385 & 0.1980 & 0.0366 & 0.0299 & 0.1684 \\
$\boldsymbol{W O}_{\mathbf{1}}$ & 0.0638 & 0.0443 & 0.0631 & 0.1767 & 0.0721 & 0.1235 & 0.2108 & 0.2359 & 0.0759 & 0.1037 \\
$\boldsymbol{W O _ { \mathbf { 2 } }}$ & 0.1938 & 0.0491 & 0.1343 & 0.0418 & 0.0893 & 0.0843 & 0.0989 & 0.0945 & 0.3919 & 0.0372 \\
$\boldsymbol{W T _ { 1 }}$ & 0.0266 & 0.0958 & 0.0329 & 0.0275 & 0.0482 & 0.0322 & 0.0858 & 0.2921 & 0.0818 & 0.1363 \\
$\boldsymbol{W T}_{\mathbf{2}}$ & 0.0298 & 0.0375 & 0.0239 & 0.3909 & 0.0242 & 0.3842 & 0.2982 & 0.1906 & 0.0458 & 0.4382 \\
\hline
\end{tabular}

Table $8 b$. The importance of each alternative strategy according to the "opportunities" and "threats" sub-factors

\begin{tabular}{|c|c|c|c|c|c|c|c|c|c|c|}
\hline & $O_{1}$ & $\mathrm{O}_{2}$ & $\mathrm{O}_{3}$ & $\mathrm{O}_{4}$ & $O_{5}$ & $T_{1}$ & $T_{2}$ & $T_{3}$ & $T_{4}$ & $T_{5}$ \\
\hline $\mathrm{SO}_{1}$ & 126 & & .283 & 18 & TC & 140 & 0 & USt & .030 & 0298 \\
\hline $\mathrm{SO}_{2}$ & 0.23 & 0 & 0.12 & 108 & 0.069 & 0.0492 & 0.053 & 0.0458 & 0.044 & 0.0934 \\
\hline$S T_{1}$ & 0.1222 & .21 & 0.21 & 0.26 & 0.07 & 0.4867 & 0.262 & 0.025 & 0.0339 & 0.0170 \\
\hline$S T_{2}$ & 00 & .066 & $0.0^{7}$ & .08 & .34 & 0.084 & 0.119 & .2 & 0.1 & 0.2156 \\
\hline$W O_{1}$ & 0.09 & 1. & 0.04 & 0.13 & 0.19 & 0.0216 & 0.04 & $0.12^{\prime}$ & 0.258 & 0.1092 \\
\hline $\mathrm{WO}_{2}$ & $0.21^{\prime}$ & .099 & 0.07 & 0.1 & 0.038 & 0.093 & 0.108 & 0.0520 & 0.058 & 0.0530 \\
\hline$W T_{1}$ & 0.0666 & 0.071 & 0.123 & 017 & 0.065 & 0.0582 & 0.293 & 0.1051 & 0.2058 & 0.4152 \\
\hline$W T_{2}$ & 0.054 & 0.036 & 0.044 & .042 & .153 & 0.066 & 0.05 & 0.3697 & 0.1692 & 0.0667 \\
\hline
\end{tabular}

Step 6. By multiplying the results regarding the global importance of the SWOT sub-factors shown in the Table 7 and the results regarding the overall importance of the alternative strategies according to the SWOT subfactors shown in Tables $8 a$ and $8 b$, the overall priority of the strategies is determined and presented in Table 9. 
Table 9. The overall priority of the strategies

\begin{tabular}{ccc}
\hline Strategy & Priority & Rank \\
\hline $\boldsymbol{S O}_{\mathbf{1}}$ & 0.1408 & $\mathbf{3}$ \\
$\boldsymbol{S O}_{\mathbf{2}}$ & 0.1108 & $\mathbf{5}$ \\
$\boldsymbol{S T}_{\mathbf{1}}$ & 0.1537 & $\mathbf{1}$ \\
$\boldsymbol{S T}_{\mathbf{2}}$ & 0.1262 & $\mathbf{4}$ \\
$\boldsymbol{W O}_{\mathbf{1}}$ & 0.1097 & $\mathbf{6}$ \\
$\boldsymbol{W O _ { 2 }}$ & 0.1097 & $\mathbf{7}$ \\
$\boldsymbol{W} \boldsymbol{T}_{\mathbf{1}}$ & 0.1045 & $\mathbf{8}$ \\
$\boldsymbol{W T}_{\mathbf{2}}$ & 0.1446 & $\mathbf{2}$ \\
\hline
\end{tabular}

According to the results obtained, Strategy $\boldsymbol{S T}_{\mathbf{1}}(0.1537)$ has priority over the other strategies when its application in Sokobanja Spa is concerned.

\section{DISCUSSION}

The results obtained by having applied the SWOT-SWARA analysis for the purpose of prioritizing the development strategies for Sokobanja Spa are as follows:

$$
S T_{1} \rightarrow W T_{2} \rightarrow S O_{1} \rightarrow S T_{2} \rightarrow S O_{2} \rightarrow W O_{1} \rightarrow W O_{2} \rightarrow W T_{2}
$$

According to these results, it is first necessary to fully appreciate the available natural resources and resolve the problem connected with business seasonality $\left(\boldsymbol{S} \boldsymbol{T}_{1}-0.1537\right)$. Then, the project proposals directed to the Republic as well as other different structures represent one of the priority tasks that should be done in the period of time to come because the Municipality of Sokobanja Spa is not capable of financing on its own the projects pointed at solving many issues related to the communal, tourism and traffic infrastructures $\left(\boldsymbol{W} \boldsymbol{T}_{\mathbf{2}}-0.1446\right)$. The application of the $\boldsymbol{W} \boldsymbol{T}_{\mathbf{2}}$ strategy will enable the overcoming of the sub-factors from within the $\boldsymbol{W}$ group and the $\boldsymbol{T}$-group that have a greater negative influence on the present tourism operation in Sokobanja Spa $\left(\boldsymbol{W}_{\mathbf{1}}-0.0644\right.$ and $\left.\boldsymbol{T}_{\mathbf{3}}-0.0793\right)$.

When stable business operations are enabled throughout the year and when the main problems with the infrastructure are solved, the next task to do is the improvement of Sokobanja Spa's tourism offer $\left(\boldsymbol{S O}_{\mathbf{1}}-0.1408\right)$. Considering the fact that the natural resources are the basis for tourism development, it is necessary to ensure their preservation and protection, simultaneously making efforts to bring the process of the privatization of the hotels to an end $\left(\boldsymbol{S} \boldsymbol{T}_{\mathbf{2}}-0.1262\right)$. Efforts should be made in the future towards the creation of a campaign that would be continually waged and well-designed, intended to target the desired group of tourists throughout the year, not only during the summer $\left(\boldsymbol{S O}_{\mathbf{2}}-0.1108\right)$. Recently, the relatively low quality of the accommodation capacities has been the main 
weakness of the destination, but the present situation would be improved by enabling a possibility of attracting resources from different funds and finishing the privatization process $\left(\boldsymbol{W O}_{\mathbf{1}}-0.1097\right)$.

Work needs to be done in building the image of Sokobanja Spa as a tourism destination of leisure, recreation, wellness and spa tourism, rather than that of only health tourism, where you can expect to receive a proper quality for the price paid $\left(\boldsymbol{W O}_{\mathbf{2}}-0.1097\right)$. In the end, it is necessary to define a set of the standards that will regulate business operations, as well as the environment protection in the territory of Sokobanja Spa. $\left(\boldsymbol{W} \boldsymbol{T}_{\mathbf{1}}-0.1045\right)$.

\section{CONCLUSION}

In this manuscript, the prioritization of the development strategy for the tourism destination of Sokobanja Spa through the application of the SWOT-SWARA analysis is demonstrated. The SWOT analysis is used for the determination of the development strategies and the imperfection connected with its inability to measure the importance of each single factor and its influence on the final strategic decision is overcome by applying the SWARA method. A comprehensive case study is performed in order to present the usability and the practical implications of the proposed analysis. The results obtained are reliable and the proposed strategies are appropriate for such an application in the present conditions. By applying the proposed strategies following the given priority order, it is possible to achieve the main goal that implies the complete utilization of Sokobanja Spa's available resource base and the better positioning of the Spa itself on the tourism market in the future.

Strategic decisions are often made in the conditions of uncertainty and on the base of incomplete pieces of information, which are very difficult to express as crisp numbers. This problem could, however, be overcome by introducing fuzzy, intuitionistic fuzzy, grey and neutrosophic numbers, the application of which could improve the proposed SWOTSWARA analysis as well. Besides, a greater number of the SWOT subfactors, as well as the development strategies included in the decisionmaking process, would enhance the quality of the performed analysis. In this case, three $D M \mathrm{~s}$ are involved; by introducing a larger number of $D M \mathrm{~s}$, however, the results obtained would be more representative. Beside that, the proposed analysis ensures a systematic, easy and transparent decisionmaking process that leads to the obtaining of adequate results. Also, in the field of decision-making in tourism, there are many questions that have to be closed and the possibilities of applying the MCDM methods have not been entirely tested yet. 


\section{REFERENCES}

Ajmera, P. (2017). Ranking the strategies for Indian medical tourism sector through the integration of SWOT analysis and TOPSIS method. International Journal of Health Care Quality Assurance, 30(8), 668-679, https://doi.org/10.1108/ IJHCQA-05-2016-0073.

Akbulak, C., \& Cengiz, T. (2014). Determining ecotourism strategies using A'WOT hybrid method: case study of Troia Historical National Park, Çanakkale, Turkey. International Journal of Sustainable Development \& World Ecology, 21(4), 380-388, http://dx.doi.org/10.1080/13504509.2014.903383.

Andrews, K. R. (1965). The concept of corporate strategy. Homewood II: Dow Jones - Irwin.

Arsić, S., Nikolić, D., \& Živković, Ž. (2017). Hybrid SWOT-ANP-FANP model for prioritization strategies of sustainable development of ecotourism in National Park Djerdap, Serbia. Forest Policy and Economics, 80, 11-26, https://doi.org/ 10.1016/j.forpol.2017.02.003.

Asadi, R. (2011). Strategies for development of Iran cultural tourism. Australian Journal of Basic and Applied Sciences, 5(8), 1021-1034.

Chai, J., Liu, J. N. K., \& Ngai, E. W. T. (2013). Application of decision-making techniques in supplier selection: A systematic review of literature. Expert Systems with Applications, 40(10), 3872-3885, https://doi.org/10.1016/j.eswa. 2012.12.040.

Coman, A., \& Ronen, B. (2009). Focused SWOT: diagnosing critical strengths and weaknesses. International Journal of Production Research, 47(20), 56775689, http://dx.doi.org/10.1080/00207540802146130.

Csirmaz, É., \& Petö, K. (2015). International trends in recreational and wellness tourism. Procedia Economics and Finance, 32, 755-762, https://doi.org/10.1016/S2212-5671(15)01458-6.

Esmaeili, A., Kahnali, R. A., Rostamzadeh, R., Zavadskas, E. K., \& Sepahvand, A. (2014). The formulation of organizational strategies through integration of freeman model, SWOT, and fuzzy MCDM methods: A case study of oil industry. Transformations in Business \& Economics, 13(3C), 602-627.

Eslamipoor, R., \& Sepehriar, A. (2014). Firm relocation as a potential solution for environment improvement using a SWOT-AHP hybrid method. Process Safety and Environmental Protection, 92(3), 269-276, https://doi.org/ 10.1016/j.psep.2013.02.003.

Hashemkhani Zolfani, S., \& Saparauskas, J. (2013). New application of SWARA method in prioritizing sustainability assessment indicators of energy system. Inzinerine Ekonomika-Engineering Economics, 24(5), 408-414, http://dx.doi.org/ 10.5755/j01.ee.24.5.4526.

Hashemkhani Zolfani, S., \& Bahrami, M. (2014). Investment prioritizing in high tech industries based on SWARA-COPRAS approach. Technological and Economic Development of Economy, 20(3), 534-553, http://dx.doi.org/10.3846/20294913. 2014.881435.

Helms, M. M., \& Nixon, J. (2010). Exploring SWOT analysis-where are we now? A review of academic research from the last decade. Journal of Strategy and Management, 3(3), 215-251, https://doi.org/10.1108/17554251011064837.

Houben, G., Lenie, K., \& Vanhoof, K. (1999). A knowledge-based SWOT-analysis system as an instrument for strategic planning in small and medium sized enterprises. Decision Support Systems, 26(2), 125-135, https://doi.org/10.1016/ S0167-9236(99)00024-X. 
Işık, A. T., \& Adalı, E. A. (2016). A new integrated decision making approach based on SWARA and OCRA methods for the hotel selection problem. International Journal of Advanced Operations Management, 8(2), 140-151, https://doi.org/10.1504/IJAOM.2016.079681.

Jamali, G., Asl, E. K., Zolfani, S. H., \& Šaparauskas, J. (2017). Analyzing large supply chain management competitive strategies in Iranian cement industries. E+ M Ekonomie a Management, 20(3), 70-83, doi: 10.15240/tui/001/2017-3-005.

Kajanus, M., Leskinen, P., Kurttila, M., \& Kangas, J. (2012). Making use of MCDS methods in SWOT analysis-Lessons learnt in strategic natural resources management. Forest Policy and Economics, 20, 1-9, https://doi.org/10.1016/ j.forpol.2012.03.005.

Karabasevic, D., Zavadskas, E. K., Turskis, Z., \& Stanujkic, D. (2016). The framework for the selection of personnel based on the SWARA and ARAS methods under uncertainties. Informatica, 27(1), 49-65.

Karabašević, D., \& Stanujkić, D. (2017). Contemporary trends of the application of Multiple Criteria Decision Making methods in the function of recruitment and selection of personnel. Megabiznis, 1(1), 65-76 (In Serbian).

Karabašević, D., Stanujkić, D., Urošević, S., Popović, G., \& Maksimović, M. (2017). An approach to criteria weights determination by integrating the Delphi and the adapted SWARA methods. Management: Journal of Sustainable Business and Management Solutions in Emerging Economies, 22(3), 15-25.

Keršuliene, V., Zavadskas, E. K., \& Turskis, Z. (2010). Selection of rational dispute resolution method by applying new stepwise weight assessment ratio analysis (SWARA). Journal of Business Economics and Management, 11(2), 243-258, http://dx.doi.org/10.3846/jbem.2010.12.

Kurttila, M., Pesonen, M., Kangas, J., \& Kajanus, M. (2000). Utilizing the analytic hierarchy process (AHP) in SWOT analysis - a hybrid method and its application to a forest-certification case. Forest Policy and Economics, 1(1), 41-52, https://doi.org/10.1016/S1389-9341(99)00004-0.

Lee, T. H., \& Liu, R. T. (2011). Strategy formulation for the recreational areas of Central Taiwan: An application of SWOT (strengths, weaknesses, opportunities, threats) analysis. Journal of Hospitality Management and Tourism, 2(3), 38-47.

Mardani, A., Jusoh, A., Zavadskas, E. K., Kazemilari, M., Ungku N.U.A., Khalifah, Z. (2016). Application of multiple criteria decision making techniques in tourism and hospitality industry: a systematic review. Transformations in Business \& Economics, 15(1), 192-213.

Mimović, P., Kocić, M., \& Milanović, M. (2012). A WOT model in selecting the optimal tourism development strategy in Vrnjačka Banja. Teme, XXXVI (2), 815-836 (In Serbian).

Ministry of Trade, Tourism and Telecommunications. (2007). Master plan of the tourism destination Soko Spa. Hosting d.o.o.: Ljubljana, Slovenia (In Serbian).

Nikolić, Đ., Spasić, J., Živković, Ž., Đorđević, P., Mihajlović, I., \& Kangas, J. (2015). SWOT-AHP model for prioritization of strategies of the resort Stara Planina. Serbian Journal of Management, 10(2), 141-150.

Oztaysi, B. (2014). A decision model for information technology selection using AHP integrated TOPSIS-Grey: The case of content management systems. KnowledgeBased Systems, 70, 44-54, https://doi.org/10.1016/j.knosys.2014.02.010.

Saaty, T. L. (1980). The Analytic Hierarchy Process: Planning, Priority Setting, Resource Allocation. McGraw-Hill: New York.

Şeker, Ş., \& Özgürler, M. (2012). Analysis of the Turkish consumer electronics firm using SWOT-AHP method. Procedia-Social and Behavioral Sciences, 58, 1544-1554, https://doi.org/10.1016/j.sbspro.2012.09.1141. 
Shahba, S., Arjmandi, R., Monavari, M., \& Ghodusi, J. (2017). Application of multiattribute decision-making methods in SWOT analysis of mine waste management (case study: Sirjan's Golgohar iron mine, Iran). Resources Policy, 51, 67-76, https://doi.org/10.1016/j.resourpol.2016.11.002.

Singh, S. P., Chauhan, M. K., \& Singh, P. (2015). Using multicriteria futuristic fuzzy decision hierarchy in SWOT analysis: an application in tourism industry. International Journal of Operations Research and Information Systems (IJORIS), 6(4), 38-56, doi:10.4018/IJORIS.2015100103.

Statistical Office of the Republic of Serbia. Statistical data on tourist traffic in Serbia. (2017). Retrieved from: http://mtt.gov.rs/download/Decembar\%202016\% 20Statisti\%C4\%8Dki\%20podaci\%20za\%20decembar\%202016.docx.

Stanujkić, D., Karabašević, D., \& Zavadskas, E. K. (2015). A framework for the selection of a packaging design based on the SWARA method. Inzinerine Ekonomika-Engineering Economics, 26(2), 181-187, http://dx.doi.org/10.5755/ j01.ee.26.2.8820.

Urošević, S., Karabašević, D., Stanujkić, D., \& Maksimović, M. (2017). An approach to personnel selection in the tourism industry based on the SWARA and the WASPAS methods. Economic Computation \& Economic Cybernetics Studies \& Research, 5l(1).

World Tourism Organization (2017a). UNWTO Annual Report 2016. UNWTO: Madrid.

World Tourism Organization (2017b). European Union short-term tourism trends, vol 1. UNWTO: Madrid.

Zolfani, S. H., Zavadskas, E. K., \& Turskis, Z. (2013). Design of products with both international and local perspectives based on Yin-Yang balance theory and SWARA method. Economic Research-Ekonomska Istraživanja, 26(2), 153166, http://dx.doi.org/10.1080/1331677X.2013.11517613.

\section{ПРИОРИТИЗАЦИЈА СТРАТЕГИЈА УСМЕРЕНИХ HA PAЗВОJ ТУРИЗМА ПРИМЕНОМ SWOT-SWARA АНАЛИЗЕ: ПРИМЕР СОКОБАЊЕ}

Габријела Поповић ${ }^{1}$, Горан Миловановић ${ }^{2}$, Драгиша Станујкић $^{\mathbf{3}}$

${ }^{1}$ Мегатренд универзитет у Београду, Факултет за менаџмент у Зајечару, Србија ${ }^{2}$ Универзитет у Нишу, Економски факултет, Ниш, Србије

${ }^{3}$ Универзитет у Београду, Технички факултет у Бору, Србија

\section{Резиме}

SWOT анализа (снаге, слабости, шансе и претње) представља веома популарно средство за дефинисање унутрашњих и спољашњих фактора који утичу на стратешке одлуке. Основни недостатак ове анализе огледа се у немогућности дефинисања тога који фактор има највећи утицај на стратешко одлучивање, као и у немогућности квантитативног изражавања значаја сваког фактора. Због тога је веома препоручљиво укључивање ВКО метода у процес одлучивања повезаног са утврђивањем значаја SWOT фактора, потфактора и приоритизацијом стратегија.

У овом раду је предложена SWOT-SWARA анализа, чији је основни циљ приоритизација стратегија које ће допринети побољшању постојећег стања Сокобање, суоченом са многим проблемима који утичу на њену атрактивност и смањење 


\section{6}

броја долазака и ноћења туриста. Три доносиоца одлуке су на основу SWOT матрице приказане у Мастер плану за туристичку дестинацију Сокобања (2007) начинили нову, те су на основу дефинисаних потфактора формулисали осам развојних стратегија. Применом SWARA методе, која је веома корисна и једноставна за примену, доносиоци одлуке извршили су приоритизацију SWOT фактора, потфактора и предложених стратегија. Коначни резултат дао је следећи редослед предложених стратегија: $\mathrm{ST}_{1} \rightarrow \mathrm{WT}_{2} \rightarrow \mathrm{SO}_{1} \rightarrow \mathrm{ST}_{2} \rightarrow \mathrm{SO}_{2} \rightarrow \mathrm{WO}_{1} \rightarrow$ $\mathrm{WO}_{2} \rightarrow \mathrm{WT}_{2}$.

Коришћење целих бројева, као и релативно мали број SWOT потфактора и предложених стратегија - представља основно ограничење овог рада. Поузданост добијених резултата биће унапређена увођењем фаза, интуитионистичких фаза, сивих или неутрософтичких бројева, као и већег броја потфактора и стратегија. Поред тога, предложена анализа је веома једноставна за примену, олакшава процес одлучивања и омогућава доношење поузданијих стратешких одлука. Предложена анализа може унапредити процес одлучивања не само у области туризма већ у сваком подручју пословања које захтева формулисање стратегија и њихову приоритизацију. 